\title{
YOĞURT MATRİKSINİN TÜKETİM SIRASINDA IN VIVO AROMA SALINIMI ÜZERİNE ETKİLERİ
}

\author{
Tülin Eker ${ }^{1}$, Turgut Cabaroğlu ${ }^{2}$ ** \\ ${ }^{1}$ Osmaniye Korkut Ata Üniversitesi, Mühendislik Fakültesi, Gıda Mühendisliği Bölümü, Osmaniye, Türkiye \\ ${ }^{2}$ Çukurova Üniversitesi, Ziraat Fakültesi, Gıda Mühendisliği Bölümü, Adana, Türkiye
}

Geliş / Received: 26.06.2019; Kabul / Accepted: 09.12.2019; Online bask1 / Published online: 19.01.2020

Eker, T., Cabaroğlu, T. (2020). Yoğurt matriksinin tüketim sırasında in vivo aroma salınımı üzerine etkileri. GIDA (2020) 45 (1): 50-60 doi: 10.15237/gida.GD19103

Eker, T., Cabaroğlu, T. (2020). The impact factors of yogurt matrix on in vivo aroma release during consumption of yogurt. GIDA (2020) 45 (1): 50-60 doi: 10.15237/gida.GD19103

\section{ÖZ}

Aroma, tüketicilerin yoğurt tercihlerini etkileyen ana etkendir. Gıdayı tüketirken oluşan aroma alg1sı, ağıda salınan aroma bileşiklerinin gıda matriksi ve insan tükürügü arasındaki etkileşimlerine bağlıdır. Yapılan araştırmalar, aroma algısının ve yoğurttan in vivo aroma salınımının birçok faktörden etkilendiğini göstermiştir. Yağ bileşeninin, yoğurdun aromasının tutuklanmasında ve algılanmasında önemli rolü vardır. Özellikle yağı azaltılmış yoğurtlarda, aromanın kontrollü salınmasını desteklemek için ilave edilen protein, yă̆, aroma tutuklayıcı bileșenlerin, kıvam verici maddelerin ve tatlandııcıların in vivo aroma salınımı ve aroma algısı üzerine farklı etkileri vardır. Bununla birlikte yoğurdun formüle edilmesi sırasında değişen tekstür de ağızda aroma salınımını etkilemektedir. Yoğurtta aroma algısı üzerine etki eden faktörleri anlamak, g1da sanayinde yenilikçi ve kabul gören gida ürünleri üretmede önemlidir. Bu derlemede yoğurdun in vivo tüketimi sırasında matriksin etkisini ortaya koyan çalışmalar incelenmiştir.

Anahtar kelimeler: Yoğurt matriksi, In vivo aroma salınımı, protein, yağ, aroma tutuklayıc1, kıvam verici, tatlandıric1

\section{THE IMPACT FACTORS OF YOGURT MATRIX ON IN VIVO AROMA RELEASE DURING CONSUMPTION OF YOGURT}

\begin{abstract}
The flavour is the main factor affecting consumers' preferences in yogurts. Flavour perception while eating depends on the volatile compounds release in the mouth influenced by the interactions of those compounds between both food components and human saliva. Several studies reported that flavour perception and in vivo aroma release from yogurt were impacted by many factors. The fat component has an important role in retention and perception of yogurt aroma. Particularly in light yogurts, protein, fat, encapsulating agent, thickening agent and sweetener added to promote controlled release of aroma, have different effects on in vivo aroma release and perception. In addition to this, the texture formed during the formulation of yogurt affects the release of aroma in the mouth. Understanding impact factors on flavour perception in yogurt is an important challenge for foodprocessing industry to produce innovative and appreciated food products. In this article, the studies determined the effect of the matrix during in vivo consumption of yogurt were reviewed.
\end{abstract}

Keywords: Yogurt matrix, in vivo aroma release, protein, fat, aroma encapsulating, thickening agent, sweetener

* Yazışmalardan sorumlu yazar / Corresponding author;

$\square$ tcabar@cu.edu.tr, @ (+90) 3223386997,

冝 $\quad(+90) 3223386614$

Tülin Eker; ORCID no: 0000-0001-9726-160X

Turgut Cabaroğlu; ORCID no: 0000-0003-1489-9929 


\section{GİRIŞ}

Üstün özelliklere sahip bir gida maddesi olan süt, fermantasyon süreciyle, raf ömrü uzatılmıs, tat ve aroması farklılaşmış, sindirilebilirliği artmış ve fonksiyonel özellik kazanmış bir ürün olan yoğurda dönüşmektedir. Yoğurdun sağlı üzerine etkilerini belirleyen çalışmalar neticesinde yoğurdun tüketimine ilişkin tüketici bilinci gittikçe artmaktadır (Kizılaslan ve Solak, 2016). Tüketiciler, tam yağlı yoğurdun tekstürel özelliklerine ve aromasina sahip ancak az yağl1 veya yağsız aynı zamanda da katkısız yoğurt talep etmektedir. $\mathrm{Bu}$ nedenle yoğurt pazar1 tüketici beklentisini karşılayacak şekilde, yoğurdun güncel teknolojik uygulamalar ile birlikte fonksiyonel (probiyotikler, lif, omega yağ asitleri) ve yağ1 ikame edecek doğal bileşenlerle desteklenmesi ile her geçen gün büyümektedir (Soukoulis vd., 2012).

Bir gidanın ağızda çiğnenmesi sırasında, aroma bileşikleri, çiğneme hareketleri ve tükürük-gıda maddesi etkileşimi ile ağız boşluğuna yayılır ve bu bileşenler koklama veya geniz yoluyla algılanırlar (Boesveldt ve de Graaf, 2017; Mosca ve Chen, 2017). Gıda matriksinin, ağızda çiğneme koşullarının veya kişiler arası farklılıkların aroma salınımı üzerine etkisini anlamak için gıdaların tüketimi sırasında kişilerin burun veya ağılarından nefes örneği almaya yarayan ve bu nefes komposizyonunu belirleyen teknikler geliştirilmiştir (Esteban-Fernández vd., 2016; Ployon vd., 2017; Frank vd., 2017; Pu vd., 2019). $\mathrm{Bu}$ teknikler genel olarak, gidalardan aroma salınımını gıdanın tüketilmesiyle eş zamanlı bir şekilde belirlenmesi veya kişilerin nefeslerindeki (in vivo) aroma bileşenlerinin gıdanın tüketilmesi sirasinda bir polimere tutturulmasi esasina dayanır. Aroma salınımı çalışmalarında kullanılan in vivo ve in vitro yöntemler daha önceki bir çalışmada detaylı olarak açıklanmıştır (Eker ve Cabaroğlu, 2018).

Tüketici tarafindan kabul edilebilirliği büyük oranda duyusal özelliklerine bağlı olan yoğurt, in vivo ve in vitro yöntemlerinin kullanıldığı birçok aroma salınımı çalışmasına konu olmuştur (SaintEve vd., 2006b; Kant vd., 2004; Decourcelle vd., 2004; Mei vd., 2004). Dinamik g1da tüketimi süreci boyunca gidadan salınan aroma maddeleri, özellikle yoğurt gibi ağızda kalma süresi kısa olan ürünler için önemli bir rol oynamaktadır (Mesurolle vd., 2013). Aroma salınımını ve algılamasını arttırmak için, ağızda aroma salınımını etkileyen faktörlerin daha iyi anlaşılması büyük önem taşımaktadır. Yoğurtta aroma algısını düzenleyen mekanizmaların daha iyi anlaşılması için literatürde tekstür-aroma veya matriks-aroma ilişkilerini araştıran çok sayıda araştırma yapılmıştır (Kant vd., 2004; Decourcelle vd., 2004; Mei vd., 2004).

$\mathrm{Bu}$ çalşşmada, yoğurtta gida otoritelerince kullanımına izin verilen gida katkı maddelerinin yoğurt matriksi içinde in vivo aroma salınımına katkısını ve duyusal özelliklerine etkisini araştıran çalışmalar derlenmiştir.

\section{YOĞURDUN BİLEŞENLERİ VE AROMA ETKILESSIIMLERİ}

Yoğurt yar1-katı fermente bir süt ürünüdür. Neredeyse dünyanın tüm ülkelerinde bilinmekte ve tüketilmektedir. Kıvam, lezzet ve aroma bakımından bir bölgeden diğerine farklilık gösterse de temel bileşenleri ve üretimi genel olarak aynıdır (Yildiz, 2016). Yoğurt, su moleküllerinin geniş bir zayıf protein ağı içinde tutuklandığ1 karmaşık, kolloidal bir sistemdir. Yoğurttaki aroma algis1, matriksinin bileşimsel, kolloidal, yapısal ve reolojik karakteri kadar sütün laktik asit bakterileri tarafindan fermantasyonu sırasinda meydana gelen biyokimyasal reaksiyonlar sonucu oluşur (Soukoulis vd., 2012). Birçok çalışmada yăg, protein türü $(\beta$ laktoglobulin, $\alpha$-laktobumin ve kazeinler), polisakkaritler, şekerler ve tatlandırıcı gibi bileşenler ile yapay aroma maddeleri ilave edilmiş model yoğurt matriksinden salınan aroma bileşenleri arasındaki ilişki araştırılmıştır (SaintEve vd., 2006a; Saint-Eve vd., 2006b; Déléris vd., 2007; Chua et al. 2017). Bu faktörlerden biri olan yağ, yoğurt pıhtısını oluşturan ağ yapıdaki temel bileşenlerden biridir. Yoğurt pihtıs1, 1sıl işlem ve asitlik etkisiyle $\kappa$-kazein ve $\beta$-laktaglobulin arasında oluşan interaksiyon sonucu proteinlerin hidrofilik niteliklerinin artmasını sağlar. $\mathrm{Bu}$ ağ yapının içine yağ globülleri de girmekte ve böylece pihtı daha stabil olmaktadır. Yağ yoğurt tekstürünü iyileştirir. Genellikle tam yağlı yoğurtlar daha s1k1, daha viskoz ve daha elastik 
özellikler gösterir (Chua vd., 2017). Yoğurt üretiminde yağın bu kadar önemli olmasının yanında son yıllarda fazla yağ tüketiminin neden olduğu sağlık problemleri nedeniyle tüketiciler az yağlı veya yağsız ürünler ile birlikte antioksidan içeriği yüksek gıdaları tüketme eğilimi göstermektedir (Zhao vd., 2018). Tüketim eğilimindeki değişiklikler ile birlikte yağı ikame edici bileşenlerle (nişasta, pektin, guar gam, keçiboynuzu gamı) zenginleştirilmiş az yağlı yoğurtlar ve çeşitli meyve püreleri, meyve karışımları, dondurulmuş meyveler, meyve reçelleri veya meyve konsantreleri ile aromalandırılmış yoğurtlar üretilmeye başlanmıştır (Voşgan vd., 2016).

Yoğurdun aromasına katkıda bulunan etmenler; i) laktik asit, ii) sütte bulunan aroma bileşenleri ve iii) fermantasyon ile oluşan spesifik aroma bileşikleri olarak sınıflandırılabilir (Tian vd., 2017; Tian vd., 2019). Yoğurt içinde alkoller, aldehitler, ketonlar, asitler, esterler, laktonlar, sülfürlü bileşikler, pirazinler ve furan türevlerini içeren 90'dan fazla farklı uçucu bileşen tespit edilmiştir (Zhao vd., 2018). Henüz kesin olmamakla birlikte yoğurtta istenen aromadan sorumlu karakteristik bileşiklerin laktik asit, asetaldehit, diasetil, asetoin ve 2-bütanon olduğu bildirilmiştir (Chen et el. 2017). Yoğurtta aroma salınımını etkileyen matriks kaynaklı faktörler aşağıda başlıklar halinde tartışılmıstır.

\section{Yağ bileşeninin aroma salınımına etkisi}

Aroma bileşikleri ile gıda bileşenleri arasındaki moleküler etkileşimler, aromanın gıdadan salınımını etkiler. Aroma bileşiklerinin hidrofobik-hidrofilik karakterleri birbirinden farklıdır. Hidrofilik aroma bileşiklerinin salınımı yağ bileşeninden bağımsız iken, hidrofobik aroma bileşiklerinin salınımı gıda içerisindeki yağ miktarı arttıkça azalır. Düşük ve yüksek miktarda yă̆ içeren peynirlerde yapılan bir çalışmada, hidrofobik aroma bileşenlerinin öncelikle yağ fazı içinde dağılacaklarını ve gıdayı tüketirken aroma bileşenlerinin uçuculuğunun yavaşlayacağ1 bildirilmektedir (Delahunty vd., 1996). Çoğu aroma bileşiği hidrofobik karakterinden dolay1 lipitler içinde çözünür. Yağ hidrofobik aroma bileşenleri için çözgen görevi görür ve gıdanın hem dokusunu etkiler hem de aroma salınımını ve alg1sını değiştirir (Chua vd., 2017). Bu nedenle az yağlı yoğurdun aroma salınımı ile tam yağlı yoğurdun aroma salınımı aynı değildir. Az yağlı yoğurtlar tüketici beklentisini kompozisyon olarak karşılar ancak duyusal olarak daha zayıf özelliktedir. Brauss vd. (1999), in vivo, Nongonierma vd. (2006), in vitro koşullarda, yağın aroma bileşenlerinin salınımını yavaşlattığını ve salınım süresini uzattığını bildirmiştir. Aroma salınımının eşzamanlı olarak izlenmesine olanak sağlayan atmosferik basınç iyonizasyonu-kütle spektrometresi (API-MS) sonuçları aroma bileşenlerinin az yağlı yoğurtlardan (\%0.2) daha hızlı ve daha yoğun bir şekilde salınırken bu bileşiklerin $\% 0.2$ yağ içeren ortamda, $\% 3.5$ ve $\% 10$ yağ içeren yoğurtlara göre daha az kalıc1 olduklarını göstermiştir (Brauss vd., 1999).

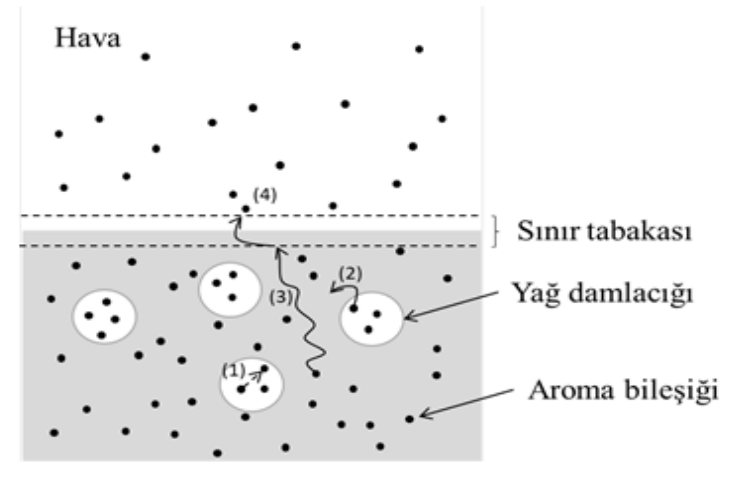

Şekil 1. Gıdadan ağız boşluğuna salınan aroma bileşiklerinin adım adım salınımını gösteren şematik diyagram 
Yağs1z yoğurt, proteinler ve polisakaritlerden oluşan kompleks bir matrikstir. Gıda sistemleri içinde bulunan protein ve polisakkarit bileşenlerinin birbiri ile etkileşime girdiği bilinmektedir. Her iki makro molekülün elektrostatik etkileşimler, hidrojen bağları ve Van der Waals kuvvetleri gibi kovalent olmayan etkileşimler ile kurduklanı ağ, aroma salınımında rol oynayan karmaşık bir yapı oluşturur (Lubbers vd., 2004).

Manda sütü yoğurdunda yağ içeriği arttıkça $L^{*}$ değeri, viskozite ve tutunabilirlik değeri artarken $a^{*}$ değeri, serum ayrılması, sertliği ve esnekliği azalmıştır. Yoğurt örneklerinin yağ içeriğindeki düşüş yapışkanlık, çiğnenebilirlik gibi tekstürel Özellikleri yanında titrasyon asitliği, $\mathrm{b}^{*}$ değeri ve Streptococcus thermophilus popülasyonunda anlaml bir değişikliğe neden olmamıştır (Akgun vd., 2016).

Önceki araștırmalar, aroma salınımının yalnızca toplam yağ içeriğine değil, aynı zamanda yağın fizikokimyasal özelliklerine de bağlı olduğunu göstermiştir (Heilig vd., 2016). Ayed vd. (2018), model ağız yöntemiyle gerçek tükürük ve yapay tükürük eşliğinde, farklı yağ-protein tipinin ve miktarının bir süt ürünü olan dondurmanın aroma salınımına etkisini araştırmıştır. Yağ tipinin aroma üzerindeki etkisi yağ miktarı ile kıyaslandığında daha az olarak bildirilmiştir. Yağ aroma salınımını proteinden daha çok etkilemiş ve yağ oranı arttıkça hidrofobik aroma bileşiği salınımı azalmıştır.

İlginç bir şekilde, bazı aroma maddelerinin de yağ ile ilgili duyusal alg1yı (yağlllık ve kremsilik gibi) etkilediği bildirilmiştir. Yağı azaltılmış, pıhtısı kırılmış yoğurtlara hindistan cevizi ve tereyağı aromaları ilave edildiğinde bu yoğurtlar yeşil elma ve badem aroması ilave edilenlere kıyasla daha kıvamlı olarak algılanmıştır. Yağ ile ilgili aroma maddelerinin ilavesi, çeşitli gida maddelerinde yağ ile ilgili duyusal özelliklerin algilanmasinı arttırmıştır (Saint-Eve vd., 2004; Syarifuddin vd., 2016; Schoumacker vd., 2017).

\section{Aroma tutuklayıcı bileşenlerin aroma salınımına etkisi}

Aroma bileşiklerinin gida üretim sürecinde gida bileşenleri ile tutuklanması (enkapsülasyonu) ve gıdanın tüketilmesi sırasında salınımının kontrol edilmesi g1da üreticileri ve aroma bilimi ile ilgilenen araştırmacılar için ilgi konusu olmuştur. Aroma bileşenlerinin g1da sistemine tutuklanması ile gıdanın işlenmesi veya depolanması sırasında, aroma bileşenlerinin kimyasal olarak değişiminin veya kaybinın önlenmesi hedeflenmektedir. Bu sebeple doğal bileșenlerin tutuklama ajanı olarak kullanılması tüketici beklentisini karșılamaktadır (Reineccius, 2019).

Aroma tutuklanmasinda öncelikli hedef, aroma bileşiğinin başarılı bir şekilde kapsüle edilmesi ve stabile edilmesidir (Reineccius, 2019). Aroma maddelerinin çok uçucu olması, polarlıklarının değişkenlik göstermesi, özellikle küçük molekül ağırlığına sahip olanlarının tutuklandığ1 kapsül duvarından kolaylıkla difüze olması ve oksidasyona duyarlı olmaları sebebi ile tutuklama işleminin diğer bileşenlere kıyasla bazı zorlukları vardır. Aromanın algılanabilmesi için ise gida tüketilirken aroma bileşiğinin g1dadan serbest kalması önemlidir. Aksi takdirde aroma başarıll bir şekilde tutuklansa bile gidayı tüketen kişi tarafindan algılanamaz. Tutuklanmış aroma bileşiklerinin yeniden salınma oranı kapsül duvarının bozulması, şişmesi ve erimesi yolu ile kontrol altına alınabilmektedir. Aroma bileşiklerinin gıdadan kontrollü bir şekilde salıverilmesinde proteinler ve karbonhidratlar gibi doğal ürünlerden elde edilen tutuklayıcı ajanların kullanımı daha ön plandadır (Goncalves vd., 2016; Tan vd., 2019; Reineccius, 2019).

$\alpha$-1,4-glikozidik bağlı glukopiranoz alt birimlerinden oluşmuş, halkalı yapıdaki nişasta türevleri olan siklodeskstrinler aroma tutuklanmasında kullanılan en basit moleküllerdir. $\beta$-siklodesktrin aroma tutuklanmasında en çok kullanılan moleküldür. Molekül yapisinda hidrofobik boşluk vardır ve aroma bileşenlerini burada tutarak kompleks oluşturur. $\mathrm{Bu}$ kompleksin stabilitesi tutuklanmış molekülün büyüklüğüne ve hidrofobik özelliklerine bağlıdır. Aroma bileşenleri hidrofobik özellikleri, 
moleküler büyüklüğü ve geometrisine bağlı olarak $\beta$-siklodesktrin ile sitokiyometrik olarak 1:1 oranlı bir şekilde kompleks oluşturur. Aroma maddesinin $\beta$-siklodesktrin ile kararlı bir kompleks oluşturması için, aroma bileşeninin hidrofobik boşluğa sığacak uygun büyüklükte bir apolar kısım ve siklodekstrinin dışında kalan, moleküle hidrojen bağları ile stabilize olan polar bir kısım içermesi gereklidir (Voilley ve Etiévant
2006). Sun vd. (1999), $\beta$-siklodesktrin ile yapılarında düz bir karbon zinciri veya polar olmayan bir fenil grubu içeren n-bütanol, benzaldehit ve siklopentanon arasinda kararlı bir etkileşim olduğunu bildirmiştir. Kant vd. (2004), $\beta$-siklodesktrin ilave edilmiş yağsız yoğurtta yapay limon aroma salınımının normal yağ içeren yoğurtla benzer olduğunu bildirmiştir.

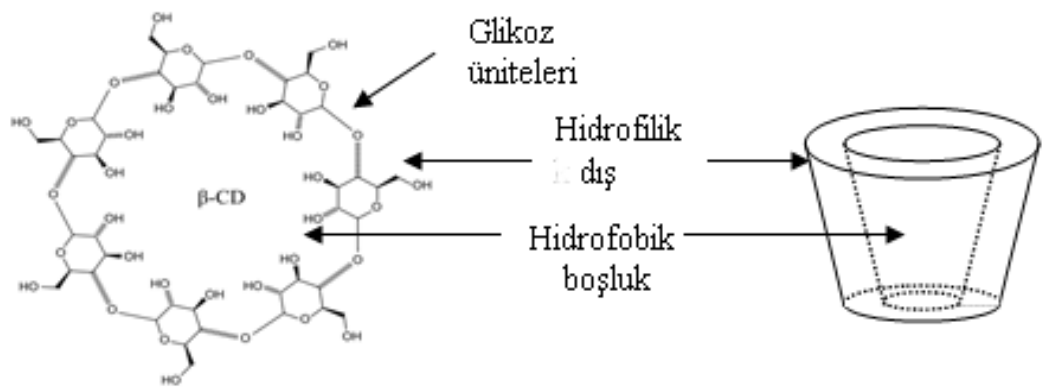

Şekil 2. $\beta$-siklodesktrin'in molekül yapısı ve şematik gösterimi

\section{Kıvam arttırıcı ve tatlandırıcı bileşenlerin aroma salınımına etkisi}

Kıvam arttırıcı bileşenlerin iki önemli görevi vardır; i) suyu tutmak ve ii) viskoziteyi arttırmak. Kıvam arttırıcı bileşenler, üç boyutlu bir jel ağ1 oluşturur ve bu ağ serbest suyu bağlayarak süt bileşenlerinin (özellikle proteinlerin) su bağlama kapasitesini arttırır. Yağı azaltılmış yoğurtlarda yap1, tekstür ve aroma algisını iyileştirmek için kıvam arttırıc1 ajanların etkisinin belirlendiği birçok çalışma yapılmıştır. Bu çalışmalarda meyve pektini, modifiye nişasta, guar gam, keçi boynuzu gam1, ksantan, karragenan ve jelatin gibi hidrokolloitlerin kıvam arttırıcı özellikleri incelenmiştir (Aziznia vd., 2008; Decourcelle vd., 2004; Mei vd., 2004).

Nişasta içindeki glikoz molekülleri, düz (amiloz) veya dall zincir (amilopektin) halinde bağlanmışlardır. Özellikle, düz amiloz fraksiyonu, iyot, lipidler, alkoller, aldehitler, terpenler ve laktonlar gibi düşük molekül ağırlıklı aroma bileşikleri ile kompleks oluşturma yeteneğine sahiptir ve bu etkileşimi tanımlamak için ligand bağlanma teorisi geliştirilmiştir. Uygun bir molekülün varllğında amiloz zinciri hidrojen bağları ile kuvvetlenerek sarmal yapıyı oluşturur. Bu sarmal yapının iç yüzeyi hidrofobik iken diş yüzeyi hidrofiliktir. Genel olarak bağlanma kuvveti, terpen gibi hacimli moleküllere kiyasla uzun ve doğrusal moleküllerde daha yüksektir (Conde-Petit vd., 2006). Nişasta-aroma kompleksi nişasta tipi, nişastanın fizikokimyasal karakteristiği, fiziksel durumu, aroma maddesinin moleküler ağırlı̆̆ ve uzunluğundan etkilenir. Farklı nişasta tipinin on farklı aroma bileşiğinden oluşan çilek aroma kompleksinin salınımı üzerine etkisi in vitro (kat1 faz mikroekstraksiyonu-gaz kromatografisi-kütle spektrometresi, (SPME-GCMS)) koşullarda belirlenmiş ve nişastanın sulu çözeltilerinden, tepe boşluğuna en çok salınan bileşik metil-hekzanoat olurken cis-3-hekzenol bu sistemde en güçlü tutulan bileşik olmuştur. Hazırlanan model nişasta tipinin aroma bileşiklerinin salınımı üzerine etkili olduğu bulunmuştur (Vidrih vd., 2009). 


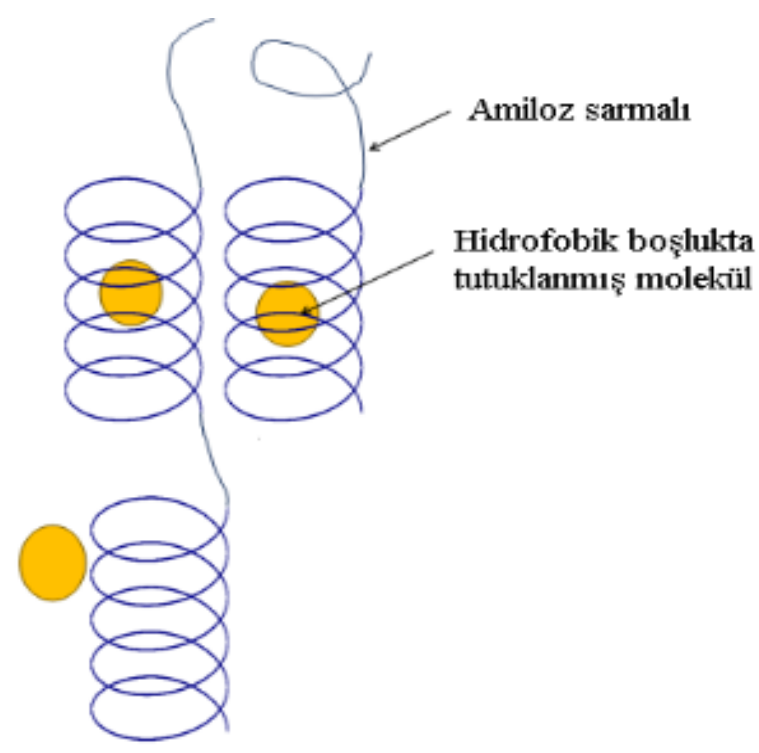

Şekil 3. Amiloz sarmal yapısı ve hidrofobik boşlukta tutulan molekülün şematik gösterimi

Yoğurda nişasta, pektin ve guar gam gibi hidrokolloitlerin ilavesinin, esterlerin aroma salınımını etkilediği bildirilmiştir (Lubbers vd., 2004). Decourcelle vd., (2004) in vitro koşullarda yağsız, pihtısı kırılmış yoğurtlarda viskozite ile birlikte tatlandırıcilar, nişasta, pektin, keçi boynuzu gamı (LBG) ve guar gum gibi kivam arttırıc1 ajanların kullanımının aroma salınımı üzerine etkisini araştırmıştır. Tatlandırıcı ve guar gamın aroma salınımı üzerine etkisi önemsiz bulunurken, LBG ve nişastanın etkisi önemli bulunmuştur. Nişastanın sarmal zincir yapısı ile aroma bileşenleri arasındaki moleküler etkileşimler tepe boşluğuna salınan aroma bileşiklerinin konsantrasyonunu azaltmıstır. LBG, ortamda serbest halde bulunan suyu bağlayarak (salting-out etkisi) tepe boşluğuna salınan aroma bileşiklerinin konsantrasyonunu arttırmıştır. Mei vd. (2004), ise in vivo koşullarda, yapay çilek aroması ilave edilmiş model yoğurtlarda tatlandırıciların (\%8 ve 12 şeker, aspartam ve früktoz şurubu-özellikle früktoz şurubunun) etilbütanoat salınımını azalttı̆̆ını, tatlandırıcıların aroma salınımı üzerine etkisinin kıvam arttırıcı ajanlardan daha fazla olduğunu bildirmiştir. Pektin ve modifiye nişastanın etil-bütanoat, etil-3metilbütanoat ve (Z)-3-hekzanol aroma salınımı üzerine etkisi önemsiz bulunmuştur. Bununla birlikte, yağ ikame maddelerinin \%1,5'den yüksek konsantrasyonlarda kullanılması yoğurdun fiziksel ve duyusal özelliklerini zayıflatmıştır. Aynı zamanda misır şurubunun, pektin jelinde de aroma salınımını yavaşlattığı ve aroma algisını azalttığ1 bilinmektedir (Lubbers vd., 2004). Pektinin ve viskozitenin aroma salınımı üzerine etkisinin araştırıldığı başka bir çalışmada, düşük şeker içerikli model gida matriksinde pektinin in vitro aroma salınımı üzerindeki etkisi önemsiz bulunmuştur (Bylaite vd., 2003). Hidroksipropilmetil selüloz (HPMC) veya karragenan ile kıvamı arttırılmış model viskoz sistemlerde in vivo aroma konsantrasyonunun değişmediğini ancak yüksek konsantrasyonlarda kullanıldığında, duyusal analiz ile belirlenen aroma yoğunluğunun azaldığı bildirilmiştir. İlave edilen kıvam arttıric maddeler ile birlikte aroma algisındaki bu düşüş i) aroma maddelerinin polimere tutunmas1/bağlanması veya ii) oluşan polimer ağ1 nedeniyle viskozitenin artması ve aroma bileşenlerinin difüzyonunun azalması ile açıklanmışır (Cook vd., 2003).

Başka bir çalışmada sakkaroz konsantrasyonundaki arțş uçuculuğu yüksek bileşiklerin (etil asetat, 2-pentanon) salınımını arttırmış, uçuculuğu az olan bileşiklerin aroma salınımını yavaşlatmıştır. Sodyum siklamatın etkisi ise önemsiz bulunmuştur (Nahon vd., 1998). Bununla birlikte, analitik olarak tespit edilen bu farklılıklar, duyusal algıda önemli bir farklilığa 
neden olmamıstır. Şeker ilavesinin aroma salınımını arttırması sıvı fazda bulunan uçuculuğu yüksek aroma bileşenlerinin konsantrasyonlarının artması ile açıklanabilir. Daha az uçucu bileşikler için aroma salınımında gözlemlenen azalma, viskozitenin artışına bağlı olarak aroma bileşiklerinin difüzyonunun yavaşlaması ile açıklanmıştır (Guichard, 2002). Bununla birlikte, benzer viskoziteye sahip hidrokolloit çözeltileri aynı aroma salınımı göstermemiştir. Bu da aroma bileşenlerinin salınımında hem viskozitesinin hem de aroma bileşenlerinin kıvam arttırıcı ajanlara bağlanmasının etkili olduğunu göstermektedir. Malkki vd. (1993), aroma bileşiklerinin hidrokolloitlere tutunmasinın ve bu maddelerin tüketim sırasında ağızdaki davranışının bazı durumlarda viskoziteden daha büyük etkiye sahip olabileceğini öne sürmüşlerdir. Polisakkaritler, polisakkarit matriksinin fizikokimyasal özelliklerine bağlı olarak aroma bileşiklerinin alıkonmasını, salınmasinı ve algılanmasinı etkilemektedir. Polisakkaritin viskozitesi ve yutulabilme kabiliyeti aroma moleküllerinin matriksten salınımını etkilemektedir. Bunun da aroma alg1sı üzerine etkisi vardır (Cook vd., 2018). $\mathrm{Bu}$ durum düşük yağlı sistemlerde aromanın dengelenmesinde bir avantaj olabilir (Cook vd., 2017).

\section{Protein bileşeninin aroma salınımı üzerine etkisi}

Kazein, kazeinat, peyniralt1 suyu proteinleri, $\beta$ laktoglobulin ve sığır serum albüminleri gibi süt proteinlerinin emülsifiye edici özellikleri çok uzun zamandır bilinmektedir ve süt ürünlerinde jelleştirme, koyulaştırma, emülsifikasyon ve köpürme gibi çeşitli özelliklerinden faydalanmak için gıda katkısı olarak kullanılırlar (Böttger vd., 2019). Globüler yapılarından dolayı denge koşulları altında bulunduğu çevre ile hidrodinamik, hidrostatik, hidrojen bağları, Van der Waals kuvvetleri ve konfigürasyonel etkileşimlerde bulunurlar (Voilley ve Etiévant, 2006). Globüler proteinlerde yapıyı stabilize eden ana etken hidrofobik etkileşimlerdir; çünkü sistem, polar olmayan gruplar ve su arasindaki temas yüzey alanını sürekli olarak azaltma eğilimindedir (Chen ve Engelen, 2012). Süt proteinleri arasinda $\beta$-Laktoglobulin ( $\beta$-LG) en çok çalış1lan protein olmuştur. $\beta$-LG birbirinden bağımsız iki bağlanma bölgesi içerir. $\beta-L G$, tersiyer yapısının bir parçası olan, retinol bağlanma bölgesi olarak da bilinen, molekülün merkezinde hidrofobik bir boşluğa sahiptir. Model sulu çözeltilerde yapılan çalışmalarda $\beta$ LG'nin hidrofobik aroma bileşiklerini merkezindeki boşluğunda alıkoyarak bu bileşiklerin uçuculuğunu azalttığ1 bildirilmiştir (Guichard ve Langourieux, 2000; Guichard, 2002; Paravisini ve Guichard, 2016). Hidrofobik bileşikler, $\beta$-LG'nin merkezinde bulunan protein boşluğuna hidrofobik etkileşimler ile bağlanmaktadır (Guichard ve Langourierux, 2000). Bu etkileşimler pH, sıcaklık, basınç gibi çevre koşullarından etkilenir (Voilley ve Etiévant, 2006).

Saint-Eve vd. (2006a), in vitro (SPME) koşullarda, kazeinat (CAS) ilavesinin yoğurtların aroma salınımını, peyniraltı suyu proteini (WP) ve süt tozu (MPO) ilaveli yoğurtlardan daha fazla geciktirdiğini bildirmiştir. Yoğurtta kazeinat konsantrasyonu arttıkça, yoğurt daha kıvamlı ve daha granüler bir yap1 kazanmıştır. Aynı matriks kompozisyonunda olsa da viskozite aroma salınımı ve algısını etkilemiş, aroma salınımı düşük viskoziteli yoğurtlarda daha fazla olmuştur. Protein ilavesi yoğurtların vizkozitesi ve tekstürü değiştiğinde ancak aroma salınımı üzerine etki etmiştir. Yoğurt tüketimi sırasında, düşük viskoziteli yoğurtlar ağız ve boğazdaki mukoza zarını daha geniş ölçüde kaplar ve in vivo olarak yoğurttan nefese salınacak aroma bileşikleri için daha geniş bir yüzey alanı oluşur. Tüketim sırasında, gıdadan ağız/burun boşluğuna salınan aroma bileşiği miktarı, transferin olacağ1 yüzey alanı ne kadar yüksek olursa o kadar yüksek olur (Saint-Eve vd., 2006b).

Chua vd. (2017), yağssz süt proteini, peynir altı suyu proteini ve sodyum kazeinat ilaveli yağsız yoğurtlarda in vitro (SPME) aroma salınımı ile birlikte reolojik özellikleri incelemiştir. \%0,5 konsantrasyonunda peynir altı suyu proteini ile zenginleştirilmiş yağsız yoğurtlar aroma salınımı ve reolojik özellikleri bakımından tam yağlı yoğurtlar ile benzer özellikler göstermiştir. Peynir altı suyu proteini, yağsız süt proteini ve sodyum 
kazeinata kıyasla diasetil salınımını daha da azaltırken, bu proteinin asetaldehit ve bütirik asit salınımı üzerine etkisi önemsiz bulunmuştur. Başka bir çalışmada ise peyniraltı suyu proteini ilavesi sodyum kazeinattan daha iyi tekstürel özellikler göstermiştir (Akalın vd., 2012).

Bruzantin vd. (2016), yağsız keçi yoğurdunun fiziksel ve duyusal özelliklerini iyileştirmek amacı ile farklı oranlarda kıvam arttırıcı ve yağsız süt tozu ilavesi ile yaptığ formülasyonlarda süt tozu ilaveli yoğurtların ticari olarak üretilen yoğurtlara en benzeyeni ve duyusal olarak en beğenileni olmuştur. Gursel vd. (2016), keçi sütüne ilave edilen peyniraltı protein izolatının ve konsantre peyniraltı suyunun keçi sütü yoğurdundaki asetaldehit konsantrasyonunu arttırdığını bildirmiştir.

\section{Meyve ve diğer bileşenlerin yoğurda ilavesinin aroma salınımı üzerine etkisi}

Yoğurt endüstrisinde kullanılan meyve karışımları i) doğrudan meyve olarak veya (ii) yapay aroma bileşikleri ile birlikte meyve parçaları şeklinde olmak üzere iki farklı şekilde ilave edilebilir (Yildiz, 2016). Mesurolle vd. (2013), meyve sertliğinin ve parçacık büyüklügünün in vivo koşullarda yağsız, pihtısı kırılmış yoğurtta aroma salınımı üzerine etkisini incelemiştir. Sertliği en yüksek meyve parçası (armut) ilaveli yoğurtlarda, in vivo koşullarda özellikle yutmadan önce, nerdeyse tüm aroma bileşenlerinin salınımı artmıştır.

Celik vd. (2006), meyve ezmesi ve şeker ilavesinin yoğurdun viskozitesini düşürdüğünü ve peynir alt1 suyunun ayrılmasını arttırdığını bildirmiştir. \%10 meyve ezmesi ve \%20 şeker ilavesi duyusal analizde tüm parametreler bakımından kabul edilebilir bulunmuştur, ancak sonuçlar arasındaki farklar istatistiksel açıdan önemsiz bulunmuştur.

Günümüzde gıda sanayinde doğal bileşenlerin kullanımına olan eğilim artmıştır. Keten tohumu müsilajı (FSM) sağlığa faydalı özellikleri ile ön plana ç1kmaktadır. Basiri vd. (2018), FSM ile birlikte karboksimetilselüloz (CMC) ilavesinin yoğurt özelliklerine etkisini incelemiştir. FSM ve FSM + CMC ilavesi yoğurtta viskoziteyi arttırarak serum ayrılmasını azaltmıstır. Ancak FSM ve CMC ilaveli yoğurtların genel kabul edilebilirlik puanlan1, kontrol grubuna kıyasla düşük çıkmıştır. Kiros vd. (2016), \%10-15 havuç suyu ve \%0.7 stabile edici madde ilavesinin yoğurdun besin değerini ve toplam karotenoid içeriğini arttırarak serum ayrılmasını baskıladığını bildirmiştir.

\section{SONUÇ}

Farklı gidalardaki aroma salınımının esaslarını anlamak, gıdaların tüketilmesi sırasında ortaya çıkacak aroma algısını açıklamak için güçlü bir araçtır. $\mathrm{Bu}$ anlayış ile birlikte bir ürünün geliştirilmesi veya formülasyonu sırasinda gida bileşiminin istenen aroma salınımını sağlayacak şekilde değisstirilmesi mümkündür. Yoğurt bileşiminde yağ bileşeninin aroma bileşiklerinin alıkonması üzerine önemli bir etkisi vardır. Yağ aroma bileşiklerini çözerek yoğurdun tüketimi sırasında aroma bileşiklerinin salınımını yavaşlatarak aroma algisını arttırmıştır. Yoğurt formülasyonunda kullanılan farklı polisakkarit ve kıvam arttırıcı maddeler, fizikokimyasal özelliğine ve miktarına bağlı olarak aroma alıkonmasında, salınımında ve algilanmasinda farklı etkiler göstermiş ancak genel olarak artan viskoziteye bağlı olarak aroma salınımını azaltmıştır. Bu da düşük yağ içeriğine sahip yoğurtlarda aromanın dengelenmesinde bir avantaj olarak gözükmektedir. Siklodekstrinler, moleküler boyutlarına ve geometrilerine bağlı olarak farklı aroma bileşikleri ile inklüzyon kompleksleri oluşturabilen en yaygin ve en basit tutuklama/kapsülleme sistemlerinden biridir. Gidalarda en yaygin kullanılan tutuklama ajanı olan $\beta$-CD, yoğurtta bazı aroma bileşiklerini tutarak bu bileşiklerin salınımını azaltmış ve $\beta$-CD ilaveli yağsız yoğurdun aroma salınımı normal yağl1 yoğurt ile benzer olmuştur.

Tüketici taleplerini karşılamak üzere sağlıklı, az yağlı veya düşük şekerli gıdaların yeniden formüle edilmesi ürünün aroma salınımını etkilemektedir. İstenen aroma profilini elde etmek için formülasyonu yapılan bileşenlerin üründeki aroma salınımını in vivo koşullarda nasıl değiştirdiğinin bilinmesi ürünün son aroma alg1s1 hakkında fikir vermesi bakımından önemlidir. 


\section{KAYNAKLAR}

Akalın, A. S., Unal, G., Dinkci, N., Hayaloglu, A.A. (2012). Microstructural, textural, and sensory characteristics of probiotic yogurts fortified with sodium calcium caseinate or whey protein concentrate. J Dairy Sci, 95(7): 3617-3628.

Akgun, A., Yazici, F., Gulec, H.A. (2016). Effect of reduced fat content on the physicochemical and microbiological properties of buffalo milk yoghurt. LWT-J Food Sci Technol, 74: 521-527.

Ayed, C., Martins, S.I., Williamson, A.M., Guichard, E. (2018). Understanding fat, proteins and saliva impact on aroma release from flavoured ice creams. Food Chem, 267: 132-139.

Aziznia, S., Khosrowshahi, A., Madadlou, A., Rahimi, J. (2008). Whey protein concentrate and gum tragacanth as fat replacers in nonfat yogurt: chemical, physical, and microstructural properties. J Dairy Sci, 91(7): 2545-2552.

Basiri, S., Haidary, N., Shekarforoush, S.S., Niakousari, M. (2018). Flaxseed mucilage: A natural stabilizer in stirred yogurt. Carbobydr Polym, 187: 59-65.

Boesveldt, S., de Graaf, K. (2017). The differential role of smell and taste for eating behavior. Percept, 46(3-4): 307-319.

Böttger, F., Dupont, D., Marcinkowska, D., Bajka, B., Mackie, A., Macierzanka, A. (2019). Which casein in sodium caseinate is most resistant to in vitro digestion? Effect of emulsification and enzymatic structuring. Food Hydrocoll, 88: 114-118.

Brauss, M.S., Linforth, R.S., Cayeux, I., Harvey, B., Taylor, A.J. (1999). Altering the fat content affects flavor release in a model yogurt system. $J$ Agric Food Chem, 47(5): 2055-2059.

Bruzantin, F.P., Daniel, J.L.P., da Silva, P.P.M., Spoto, M.H.F. (2016). Physicochemical and sensory characteristics of fat-free goat milk yogurt with added stabilizers and skim milk powder fortification. J Dairy Sci, 99(5): 3316-3324.

Bylaite, E., Meyer, A.S., Adler-Nissen, J. (2003). Changes in macroscopic viscosity do not affect the release of aroma aldehydes from a pectinaceous food model system of low sucrose content. J Agric Food Chem, 51(27): 8020-8026.
Celik, S., Bakırc1, I., Şat, I.G. (2006). Physicochemical and organoleptic properties of yogurt with cornelian cherry paste. Int $J$ Food Prop, 9(3): 401-408.

Chen, C., Zhao, S., Hao, G., Yu, H., Tian, H., Zhao, G. (2017). Role of lactic acid bacteria on the yogurt flavour: A review. Int J Food Prop, 20(sup1): S316-S330.

Chen, J., Engelen, L. (eds) (2012). Food oral processing: fundamentals of eating and sensory perception. Blackwell Publishing, UK, 114 p.

Chua, D., Deeth, H.C., Oh, H.E., Bansal, N. (2017). Altering the casein to whey protein ratio to enhance structural characteristics and release of major yoghurt volatile aroma compounds of nonfat stirred yoghurts. J Dairy Sci, 74: 63-73.

Conde-Petit, B., Nuessli, J., Heinemann, C., Escher, F. (2006). From Helical Starch Inclusion Complexes to Supramolecular Starch Assemblies. In NSTI Nanotech 2006: 2006 NSTI Nanotechnology Conference and Trade Show, Boston, May 7-11, 2006, NSTI, p701-704.

Cook, D.J., Linforth, R.S., Taylor, A.J. (2003). Effects of hydrocolloid thickeners on the perception of savory flavors. J Agr Food Chem, 51(10): 3067-3072.

Cook, S.L., Bull, S.P., Methven, L., Parker, J.K., Khutoryanskiy, V.V. (2017). Mucoadhesion: A food perspective. Food Hydrocoll, 72: 281-296.

Cook, S.L., Methven, L., Parker, J.K., Khutoryanskiy, V.V. (2018). Polysaccharide food matrices for controlling the release, retention and perception of flavours. Food Hydrocoll, 79: 253261.

Decourcelle, N., Lubbers, S., Vallet, N., Rondeau, P., Guichard, E. (2004). Effect of thickeners and sweeteners on the release of blended aroma compounds in fat-free stirred yoghurt during shear conditions. Int Dairy J, 14(9): 783-789.

Delahunty, C.M., Piggott, J. R., Conner, J.M., Paterson, A. (1996). Comparison of dynamic flavour release from hard cheeses and analysis of headspace volatiles from the mouth with flavour perception during consumption. J Sci Food Agric, 71(3): 273-281. 
Déléris, I., Lauverjat, C., Tréléa, I. C., \& Souchon, I. (2007). Diffusion of aroma compounds in stirred yogurts with different complex viscosities. J Agric Food Chem, , 55(21): 8681-8687.

Eker, T., Cabaroğlu, T. (2018). Gıdaların Tüketilmesi Sirasinda Retronazal Yolla Aroma Salınımının Belirlenmesi. GIDA, 43(1): 64-77.

Esteban-Fernández, A., Rocha-Alcubilla, N., Muñoz-González, C., Moreno-Arribas, M.V., Pozo-Bayón, M.Á. (2016). Intra-oral adsorption and release of aroma compounds following inmouth wine exposure. Food Chem, 205: 280-288.

Frank, D., Kaczmarska, K., Paterson, J., Piyasiri, U., Warner, R. (2017). Effect of marbling on volatile generation, oral breakdown and in mouth flavor release of grilled beef. Meat Sci, 133, 61-68.

Goncalves, A., Estevinho, B.N., Rocha, F. (2016). Microencapsulation of vitamin A: A review. Trends Food Sci Technol, 51: 76-87.

Guichard, E. (2002). Interactions between flavor compounds and food ingredients and their influence on flavor perception. Food Rev Int, 18(1): 49-70.

Guichard, E., Langourieux, S. (2000). Interactions between $\beta$-lactoglobulin and flavour compounds. Food Chem, 71(3): 301-308.

Guichard, E., Salles, C., Morzel, M. Le Bon A. M. (eds) (2017). Flavour: From food to perception, John Wiley \& Sons, Ltd. Published.

Gursel, A., Gursoy, A., Anli, E. A. K., Budak, S. O., Aydemir, S., Durlu-Ozkaya, F. (2016). Role of milk protein-based products in some quality attributes of goat milk yogurt. J Dairy Sci, 99(4): 2694-2703.

Heilig, A., Heimpel, K., Sonne, A., Schieberle, P., Hinrichs, J. (2016). An approach to adapt aroma in fat-free yoghurt systems: Modelling and transfer to pilot scale. Int Dairy J, 56: 101-107.

Kant, A., Linforth, R.S., Hort, J., Taylor, A.J. (2004). Effect of $\beta$-cyclodextrin on aroma release and flavor perception. J Agric Food Chem, 52(7): 2028-2035.
Kızılaslan, N. ve Solak, İ. (2016). Yoğurt ve İnsan Sağllğ̆1 Üzerine Etkileri. Gariosmanpaşa Bilimsel Arastırma Dergisi, (12): 52-59.

Kiros, E., Seifu, E., Bultosa, G., Solomon, W.K. (2016). Effect of carrot juice and stabilizer on the physicochemical and microbiological properties of yoghurt. LWT-J Food Sci Technol, 69: 191-196.

Lubbers, S., Decourcelle, N., Vallet, N., Guichard, E. (2004). Flavor release and rheology behavior of strawberry fatfree stirred yogurt during storage. J Agric Food Chem, 52(10): 30773082.

Malkki, Y., Heinio, R.L., Autio, K. (1993). Influence of oat gum, guar gum and carboxymethyl cellulose on the perception of sweetness and flavour. Food Hydrocoll, 6(6): 525532.

Mei, J.B., Reineccius, G.A., Knighton, W.B., Grimsrud, E.P. (2004). Influence of strawberry yogurt composition on aroma release. J Agric Food Chem, 52(20): 6267-6270.

Mesurolle, J., Saint-Eve, A., Déléris, I., Souchon, I. (2013). Impact of fruit piece structure in yogurts on the dynamics of aroma release and sensory perception. Molecules, 18(5): 6035-6056.

Mosca, A.C., Chen, J. (2017). Food-saliva interactions: Mechanisms and implications. Trends Food Sci Technol, 66: 125-134.

Nahon, D. F., Navarro y Koren, P.A., Roozen, J.P., Posthumus, M.A. (1998). Flavor release from mixtures of sodium cyclamate, sucrose, and an orange aroma. J Agric Food Chem, 46(12): 49634968.

Nongonierma, A.B., Springett, M., Le Quéré, J.L., Cayot, P., Voilley, A. (2006). Flavour release at gas/matrix interfaces of stirred yoghurt models. Int Dairy J, 16(2): 102-110.

Paravisini, L., Guichard, E. (2016). Interactions between aroma compounds and food matrix. In E. Guichard, C. Salles, M. Morzel, \& A. Le Bon (Eds.), Flavour: From food to Perception, Chichester, West Sussex, UK: John Wiley \& Sons., p208-234. 
Ployon, S., Morzel, M., Canon, F. (2017). The role of saliva in aroma release and perception. Food Chem, 226: 212-220.

Pu, D., Zhang, H., Zhang, Y., Sun, B., Ren, F., Chen, H., Xie, J. (2019). Characterization of the oral breakdown, sensory properties, and volatile release during mastication of white bread. Food Chem, 298 (2019): 125003.

Reineccius, G. (2019). Use of proteins for the delivery of flavours and other bioactive compounds. Food Hydrocoll, 86: 62-69.

Saint-Eve, A., Kora, E. P., Martin, N. (2004). Impact of the olfactory quality and chemical complexity of the flavouring agent on the texture of low fat stirred yogurts assessed by three different sensory methodologies. Food Qual Prefer, 15(7-8); 655-668.

Saint-Eve, A., Martin, N., Guillemin, H., Sémon, E., Guichard, E., Souchon, I. (2006a). Flavored yogurt complex viscosity influences real-time aroma release in the mouth and sensory properties. J Agric Food Chem, 54(20): 7794-7803.

Saint-Eve, A., Lévy, C., Martin, N., Souchon, I. (2006b). Influence of proteins on the perception of flavored stirred yogurts. J Dairy Sci, 89(3): 922933.

Schoumacker, R., Martin, C., Thomas-Danguin, T., Guichard, E., Le Quéré, J. L., Labouré, H. (2017). Fat perception in cottage cheese: The contribution of aroma and tasting temperature. Food Qual Prefer, 56, 241-246.

Soukoulis, C., Biasioli, F., Aprea, E., Schuhfried, E., Cappellin, L., Märk, T.D., Gasperi, F. (2012). PTR-TOF-MS analysis for influence of milk base supplementation on texture and headspace concentration of endogenous volatile compounds in yogurt. Food Bioprocess Tech, 5(6): 2085-2097.

Sun, D., Chen, J., Lu, W., Zheng, X. (1999). Heats of adsorption of some organic compounds on $\beta$ cyclodextrin determined by gas-solid chromatography. J Chromatogr, 864(2): 293-298.
Syarifuddin, A., Septier, C., Salles, C., ThomasDanguin, T. (2016). Reducing salt and fat while maintaining taste: An approach on a model food system. Food Qual Prefer, 48: 59-69.

Tan, S., Ebrahimi, A., Langrish, T. (2019). Smart release-control of microencapsulated ingredients from milk protein tablets using spray drying and heating. Food Hydrocoll, 92: 181-188.

Tian, H., Shen, Y., Yu, H., He, Y., Chen, C. (2017). Effects of 4 probiotic strains in coculture with traditional starters on the flavor profile of yogurt. J Food Sci, 85(5): 1693-1701.

Tian, H., Shi, Y., Zhang, Y., Yu, H., Mu, H., Chen, C. (2019). Screening of aroma- producing lactic acid bacteria and their application in improving the aromatic profile of yogurt. J Food Biochem, e12837.

Vidrih, R., Zlatic, E., Hribar, J. (2009). Release of strawberry aroma compounds by different starcharoma systems. Czech J Food Sci, 27: S58-S61.

Voilley, A., Etiévant, P. (eds.). (2006). Flavour in Food. Taylor \& Francis, CRC Press, the USA, 177p.

Voşgan, Z., Dumuța, A., Mihali, C., Mihalescu, L., Dippong, T., Moldovan, A. (2016). The Influence of the Fruits Addition on the Quality Characteristics of Yogurt. J Anim Sci Biotechnol, 49(2): 86-90.

Yildiz, F. (ed). (2016). Development and manufacture of fogurt and other functional dairy products. CRC press, the USA, 5p.

Zhao, L., Feng, R., Ren, F., Mao, X. (2018). Addition of buttermilk improves the flavor and volatile compound profiles of low-fat yogurt. LWT-J Food Sci Technol, 98: 9-17. 